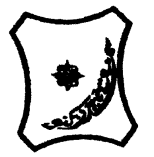

Bayero Journal of Pure and Applied Sciences: 10(1): 53 - 56

ISSN 2006 - 6996

\title{
TO GENOTYPE AND PHOSPHORUS SOURCE ON P-POOR ALFISOLS IN TWO NIGERIAN AGRO-ECOLOGIES
}

\author{
Gabasawa, A.I. ${ }^{* 1}$, Yusuf, A.A ${ }^{1}$, Iwuafor, E.N.O. ${ }^{1}$ and Echekwu, C.A. ${ }^{2}$ \\ ${ }^{1}$ Department of Soil Science, Faculty of Agriculture/Institute for Agricultural Research, Ahmadu \\ Bello University, P.M.B. 1044, Samaru, Zaria, Nigeria. \\ ${ }^{2}$ Department of Plant Science, Faculty of Agriculture/Institute for Agricultural Research, Ahmadu \\ Bello University, P.M.B. 1044, Samaru, Zaria, Nigeria. \\ ${ }^{* 1}$ Corresponding author: algabasawiyyu@yahoo.com
}

ABSTRACT

Legumes require substantial quantities of phosphorus $(P)$ for effective growth and yield. Under deficient conditions, $P$ fertilisation will improve these. Field experiments were conducted in 2016 cropping season, at two Nigerian agro-ecologies, to evaluate effects of genotype and $P$ source on yield of groundnuts grown on P-poor soils. The experiments were conducted at two experimental sites of the Institute for Agricultural Research, Ahmadu Bello University, Zaria (Minjibir and Samaru). The treatments consisted of 16 groundnut genotypes and three $P$ sources. The $P$ source was laid out in main- and genotype in sub-plot of a split plot design with four replicates. Data on pods, haulms and chlorophyll content (CC) were observed. There was no significant $(P>0.05)$ difference between the genotypes in terms of pod yield, although higher pod yield was recorded at Samaru than Minjibir. SAMNUT 22 recorded the highest haulm yield (27.85 $\left.\mathrm{g}_{\text {plant }}{ }^{-1}\right)$ among all the genotypes, while SAMNUT 21 (18.57 g plant $^{-1}$ ) and SAMNUT 24 (18.18 $\left.\mathrm{g} \mathrm{plant}^{-1}\right)$, which were statistically similar, recorded the least haulm yield. Highest CC was recorded in SAMNUT $23\left(40.39 \mathrm{mg} \mathrm{plant}^{-1}\right)$, which was at par with ICGV-IS 07083 (39.06 mg plant ${ }^{-1}$ ) while Kwankwaso had the lowest (34.18 mg plant ${ }^{-1}$ ) CC. Higher CC and haulm yield were recorded at Minjibir than at Samaru. The $P$ source significantly contributed to dry haulm $(P<0.05)$ and pod $(P<0.01)$ yields, but not in terms of $C C(P>0.05)$.

Keywords: Alfisols, genotype, haulm yield, Nigerian agro-ecologies, pod yield, P-poor

\section{INTRODUCTION}

Grain legumes, such as groundnut (Arachis hypogaea), are important components of the cropping system of the Nigerian Savannah zones. They help in improving soil fertility by fixing atmospheric nitrogen and promoting soil microbes and their activities. As far back as about 7,600 years Archaeologists discovered the oldest Arachis hypogaea specimen in Peru. Later the plant was spread all over the world by European traders. Groundnut was initially considered mainly as a garden crop, for much of the colonial period of North America, but it was later used mostly as animals feedstock until the 1930s (Dillehay, 2007). The crop is grown on large scale and mostly in India, China, Nigeria, USA, Myanmar, Indonesia, Sudan, Senegal, Argentina and Vietnam (Singh, 2011). Phosphorus $(\mathrm{P})$ has been labelled as one of the most critical nutrients for legumes. Low level of soil available $\mathrm{P}$ and large crop response to $\mathrm{P}$ fertilisers application is common for both cereals and legumes in the savannah zones of
West Africa (Lekberg and Koide, 2005). Some problems are, however, associated with a required efficient management of $P$ in tropical soils. Direct application of abundant rock phosphate found in the tropics, for example, is deemed not reliable due to its low solubility. Soluble $P$ fertilisers, on the other hand, are often expensive and can be fixed into plant unavailable forms by iron ( $\mathrm{Fe}$ ) and aluminium (Al) oxides found in tropical soils.

Various research revelations, however, indicated that inter- and intra-specific differences exist in the ability of legumes to grow on low or high $\mathrm{P}$ soils (Sanginga et al., 2000). The importance of identifying relatively high yielding genotypes under various $P$ conditions cannot be over measured (Singh, 2011). This study therefore sought to evaluate effects of genotype and P source on chlorophyll content; and pod and haulm yields of groundnuts grown on P-poor soils in two agroecologies of Nigeria. 


\section{MATERIALS AND METHODS}

Sixteen (16) groundnut genotypes, including a non-nodulating groundnut isoline (ICGL 5) used as a control, and $3 \mathrm{P}$ sources were evaluated in the Nigerian Sudan savannah at Minjibir $\left(12^{0}\right.$ 8.73' $\mathrm{N}$ and $8^{\circ} 39.97^{\prime} \mathrm{E}$ ), and Northern Guinea savannah at Samaru $\left(11^{\circ} 11^{\prime} \mathrm{N}\right.$ and $\left.7^{\circ} 36^{\prime} \mathrm{E}\right)$. The other genotypes were: ICGV-IS 07815, ARRORS ICGX $000201 / 5 / \mathrm{P}_{4} / \mathrm{P}_{10}$, ARRORS ICGXSM 00017/5/ $/ \mathrm{P}_{15} / \mathrm{P}_{2}$, ICGX-SM 00010/5/ $/ \mathrm{P}_{15} / \mathrm{P}_{1}$, ICGV-IS 07083, ICIAR 6AT, ICIAR 7B, Kwankwaso, and SAMNUT 10, SAMNUT 11, SAMNUT 14, SAMNUT 21, SAMNUT 22, SAMNUT 23 and SAMNUT 24 . The $3 \mathrm{P}$ rates were respectively at 0,30 , and $90 \mathrm{~kg} \mathrm{P}_{2} \mathrm{O}_{5} \mathrm{ha}^{-1}$.

The treatments, replicated 4 times, were, therefore, the 16 genotypes, which were in the sub-plot; and the $3 \mathrm{P}$ sources in the main plot. The last two rates were sourced from single superphosphate (SSP) at $30 \mathrm{~kg} \mathrm{P}_{2} \mathrm{O}_{5} \mathrm{ha}^{-1}$, and Sokoto rock phosphate (SRP) at $90 \mathrm{~kg} \mathrm{P}_{2} \mathrm{O}_{5} \mathrm{ha}^{-1}$ (which was arrived at following the phosphate rock analysis). Data were collected on chlorophyll content (CC); and pod and haulm yields. The Spad-502Plus chlorophyll metre was used for CC data collection.

\section{Statistical analysis}

The data generated were subjected to analysis of variance (ANOVA) using the Generalised Linear Model (GLM) of the ANOVA using statistical analysis system (SAS 9.4) package. Means that were significantly different at $\mathrm{P} \leq 0.05$ were separated using The Duncan's multiple range test (DMRT).

\section{RESULTS AND DISCUSSION}

Generally genotype significantly $(P<0.0001)$ contributed to CC, but not $(P<0.05)$ in terms of pod and haulm yields. Location significantly $(P<0.0001)$ contributed dry haulm and pod yields of the genotypes, in addition to the CC $(P<0.0001) \quad($ Table 1$)$. The $P$ source also contributed significantly in terms of dry haulm $(P<0.05)$ and pod $(P<0.01)$ yields, but not in terms of CC $(P<0.05)$ (Table 1$)$. Genotypes grown at Minjibir significantly recorded higher CC than those at Samaru. The main treatment effects for all the parameters were significant $(P<0.05)$ except for the effects of genotype and that of $P$ Source respectively on pod yield and CC. The genotype SAMNUT 23 had the highest CC, but was statistically at par with ICGV-IS
07083 (Table 1). This indicated their potential of fixing higher atmospheric nitrogen $\left(\mathrm{N}_{2}\right)$ into the soils. Although at par with the reference isoline (ICGL 5), Kwankwaso recorded the lowest CC. Relationship exists between CC of a plant and its pod yield and $\mathrm{N}$ concentration. Therefore, the CC can be used to compliment $\mathrm{N}_{2}$ fixation measurement, hence its importance in estimating biological $\mathrm{N}_{2}$ fixation potentials of genotypes (Richardson et al., 2001).

SAMNUT 22 produced significantly $(P<0.05)$ higher dry haulm yield than the statistically similar SAMNUT 21 and SAMNUT 24 (Table 1). A significantly higher dry haulm yield was also observed in the Sudan Savannah Minjibir than at NGS Samaru. This may readily explain the low pod yield recorded in the former location, as the two yields are usually inversely related (Table 1). Significantly higher pod yield was, however, recorded at NGS Samaru than at Sudan Savannah Minjibir. This may, in a way, explain why the Sudan Savannah Minjibir recorded the highest dry haulm yield. It may also possibly be due to the differences in time duration before sampling. A non-significant haulm yield of groundnuts was observed in SSP than in SRP in a study by Musa et al. (2015). They however, also reported an increase in pod yield of groundnut due to the application of SRP.

There were significant contributions of location by genotype interactions in terms of CC $(P<0.0001)$ and pod yield $(P<0.01)$; and that of location by $P$ source in terms of CC $(P<0.05)$ and pod $(P<0.05)$ yield (Table 1$)$. Generally, higher CC was observed at Minjibir than Samaru (Figure 1), whereas higher pod yield was recorded at Samaru than Minjibir (Figure 3). Kwankwaso, at Sudan Savannah Minjibir, had the highest pod yield record of 17 pods plant $^{-1}$, among all the genotypes, but was at par with SAMNUT 21 and SAMNUT 22 (15 pods plant ${ }^{-1}$ each) in same agro-ecology. The least yield, of 1 pod plant $^{-1}$, was also recorded for Kwankwaso in the Northern Guinea Savannah (NGS) at Samaru. Based on $P$ source, however, the highest pod yield was recorded for $90 \mathrm{~kg}$ SRP in the NGS Samaru, and was followed by $30 \mathrm{~kg}$ SSP. There was no significant $(P<0.05)$ difference between the $P$ sources in terms of the parameter in Sudan Savannah agro-ecology (Figure 4). 
Table 1: Effects of genotype, location and $P$ source on chlorophyll content; and haulms and pod yields of groundnut genotypes grown in 2016 cropping season in Sudan agro-ecological Minjibir (Kano State) and Northern Guinea agro-ecological Samaru (Kaduna State)



Figure 1: Location-Genotype interaction effect on CC Figure 2 Location-P Source interaction effect on CC 

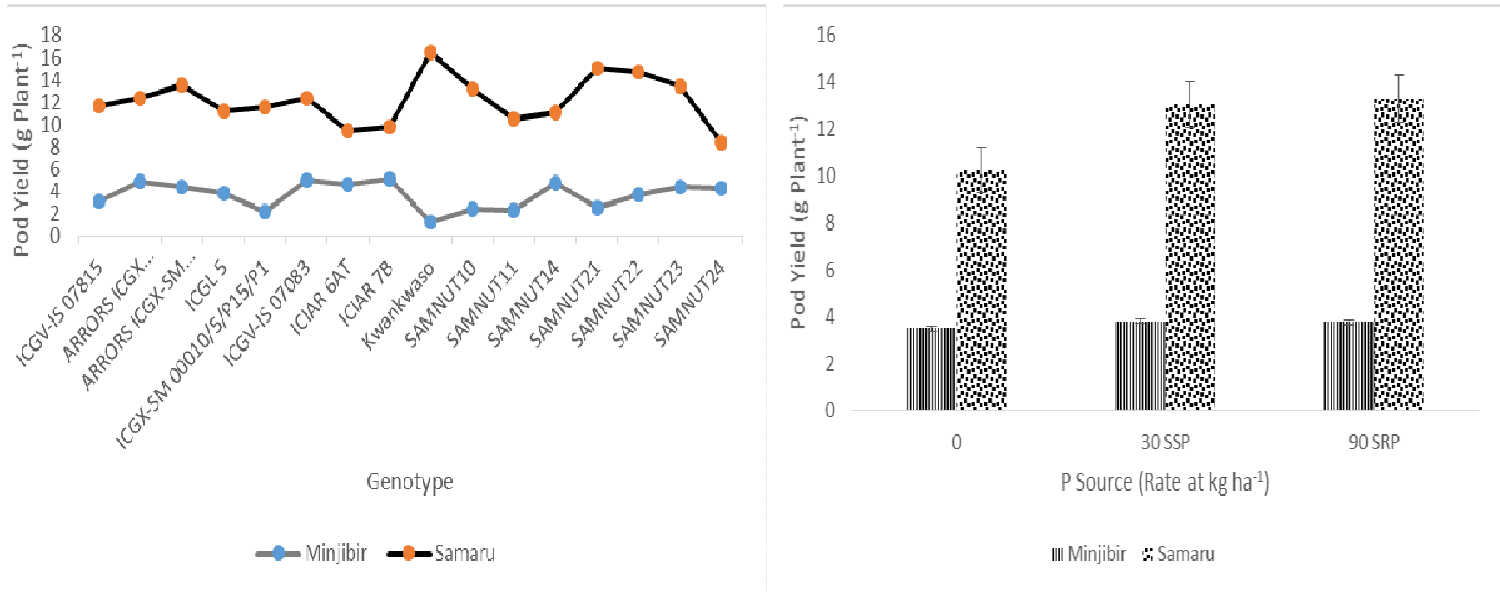

Figure 3 Location-Genotype interaction effect on Pod yield

\section{CONCLUSION}

This study found out that an agro-ecology of production had a significant role in the performance of groundnuts. Highest chlorophyll content was recorded in Sudan agro-ecology at Minjibir, higher pod yield was recorded at Northern Guinea agro-ecology Samaru than the Sudan agro-ecology Minjibir. Highest pod yield at $90 \mathrm{~kg}$ SRP was recorded at Samaru and was followed by $30 \mathrm{~kg}$ SSP. This indicated the wide

\section{REFERENCES}

Dillehay, T.D. (2007). Earliest-known Evidence of Peanut, Cotton and Squash Farming Found. Pp. 06-29.

Lekberg, Y. and Koide, R.T. (2005). Arbuscular Mycorrhizal Fungi, Rhizobia, Available $P$ and Nodulation of Groundnut (Arachis hypogaea) in Zimbabwe. Agriculture Ecosystems and Environment. 110: 143148.

Musa, M., Singh, A. and Take-tsaba, A.I. (2015). Influence of Phosphorus Sources on the Yield and Yield Components of Groundnut (Arachis hypogaea L.) Varieties in Sokoto, Semi-arid Zone of Nigeria. International Journal of Plant \& Soil Science. 7(3): 186191. ISSN: 2320-7035.
Figure 4 Location-P Source interaction effect on pod yield

diversity existing between the two agroecologies and the potentials in most of the genotypes for featuring in a successful mixed farming practices for farmers interested in a sustainable and environment-friendly crop and animal production.

\section{Acknowledgement}

The support of the Institute for Agricultural Research (IAR), ABU Zaria is highly appreciated.

Richardson, A.E., Hadobas, P.A. and Hayes, J.E. (2001). Extracellular Secretion of Aspergillus phytase from Arabidopsis Roots Enables Plants to Obtain Phosphorus from Phytate. Plant Journal. 25: 1-10.

Sanginga, N., Lyasse, O. and Singh, B.B. (2000). Phosphorus Use Efficiency and Nitrogen Balance of Cowpea Breeding Lines in a Low P Soil of the Derived Savannah Zone in West Africa. Plant and Soil. 220:119-128.

Singh, A.L. (2011). Physiological Basis for Realizing Yield Potentials in Groundnut. Advances in plant Physiology, Vol. 12. Hemantranjan, A. (Ed.). Scientific Publishers (India), Jodhpur, India, pp. 131-242. 